\title{
Public organisations and innovation for smart and sustainable working
}

\author{
Mauro Romanelli ${ }^{1}$ \\ ${ }^{1}$ University of Naples Parthenope, Department of Business and Economics, 80132 Napoli, Italy
}

\begin{abstract}
Public organisations are developing the potential of information technology to drive smart working as collaborative innovation in order to shape sustainable organisation for public value creation. Smart working is emerging as a new way to enable the work relationship as a framework which fosters collaborative innovation. Public organisations are embracing smart working mind set and practices as a way to enhance collaborative innovation and achieve sustainability as a vision for innovation and change in managing res publica, developing the social and human side in collaborative smart working by using the potential of information technology.
\end{abstract}

\section{Introduction}

Today, the advent of information and communication technology (ICT) is leading to digital, smart, agile and sustainable public organisations. Public organisations are rethinking a smart view in order to achieve sustainability as a vision for change, following both a service logicdriven and public value management-oriented view [1, $2,3,4]$, promoting cooperation and governance networks within social ecosystems [5], driving innovative collaboration [6].

Smart and sustainable organisations perform better [7], developing the human capital [8,9], promoting collaborative innovation within work environments [10], working with people, empowering them and enhancing their participation at work [11], enabling employees and managers within collaborative spaces [12]. Sustainable organisational future refers to long term strategic and orientation by supporting management commitment to improvement and innovation $[13,14]$.

ICT is opening up the way to smart and sustainable public organisations which drive innovation to enable efficiency and effectiveness, to deliver services and operations [15], to serve the public interest [16] by designing collaborative processes that involve private and public organisations to support value creation [17]. The advent of ICT supports open and public innovation within a networked governance [18, 19], and helps public organisations to enable citizens as active coproducers of social, democratic and public value [20].

Smart government helps successful modernisation opening up to digital and smart public organisations as drivers of public value creation and innovation [15, 21]. The advent of pandemic Covid-19, in virtue of the rise of a new coronavirus (Sars-CoV2), which is able to infect also the humans, and cause severe acute respiratory syndrome-related coronavirus (Sars-CoV), has led to a worldwide health crisis which impacted the life of people and organisations, leading to satisfying solutions to ensure the continuity of organisational performances at work. Companies have redesigned the organisational arrangements, by accelerating the digitalisation of processes and services as a key driver of innovation at work, leading to an increase of remote working, teleworking, online and smart working practices. During the most acute phase of the emergence from Covid-19, for example, smart working involved the $97 \%$ of large companies, the $94 \%$ of Italian public administrations and the $58 \%$ of Small and Medium Enterprises (SMEs), for a total of 6.58 million agile workers, about one third of Italian employees, more than ten times more than the 570 thousand surveyed in 2019 [22]. Employees have experienced a different way of working smart coherently with rethinking the organisation as becoming smart organisation developing the potential of ICT [23]. During pandemic Covid-19 health crisis, the smart working was emerging as innovative phenomenon and work re-design experiment, driving cultural and organisational changes [24], and empowering managers and followers in improving the ICT-enabled work relationships [25]. While teleworking implies to work at a distance from the company's main office and the use of information technology in response to energy crisis in the early ' $70 \mathrm{~s}$ [26, 27], the pandemic-enabled digitalisation is leading to smart work and organisations. Public managers play a key role in driving the organisation to achieve the desired objectives [28], promoting collaborative practices, behaviours and management styles across governmental boundaries [29]. Even if there are several studies that investigate the concepts of smartness and sustainability regarding public organisations, the relationships between the practices that enable public organisations as smart and sustainable organisations and the role of collaborative innovation in

\footnotetext{
* Corresponding author: mauro.romanelli@uniparthenope.it
} 
work and organisational environments are not yet well investigated. There are few studies that focus on digitalisation, innovation at work and collaborative innovation.

Investigating the relationship between public organisations achieving sustainability and the use of information technology to drive collaborative innovation and support work re-design is still an unexplored area. The rise of pandemic health crisis has accelerated processes of technology-driven and social-oriented collaborative innovation.

The research question refers to understand how public organisations develop the potential of ICT and digital technology to drive innovation as a key source that enables public organisations to identify smart and sustainable pathways.

The aim of this study is to elucidate how public organisations are becoming smart and sustainable working organisations driving collaborative innovation. Sustainability-oriented and value-oriented public organisations adopt a service logic view enabling the service users to actively contribute to value creation [1], driving the co-production of services within communities as a means to support innovation $[18,30$, 31]. ICT helps public organisations to work through networks that involve private and public actors, strengthening collaboration for service innovation, developing knowledge and capabilities in the pursuit of public goals [32]. ICT is driving digital and smart public organisations to support public value creation processes and develop open innovation that enables better processes and performances within communities and ecosystems [33]. Public managers construct community shared values, interacting with citizens, enhancing effectiveness and accountability within society [34].

The paper is structured in sixth sections. Following the introduction and methodological section, in the third paragraph, the debate on public innovation is conducted through the lens of collaborative innovation as theoretical background. In the fourth paragraph, the role of information technology leading to smart and sustainable public organisations is elucidated. In the fifth paragraph, the smart working is conceived as collaborative innovation enabling collaborative spaces and enhancing the employee-manager relationships. Finally, discussion and conclusions are outlined.

\section{Methodological section}

The study is theoretical and relies on a literature review and analysis relating to public organisations that aim to drive innovation by embracing information technology in order to develop smartness and sustainability, by opening to smart working as collaborative innovation and strengthening digital and smart platforms to contribute to value creation for public wealth. The research is exploratory and considers some fields of study on public organisations. The role of digital and interactive information and communication technology is central for innovation within organisations. The use of information technology concerns both the fields of research related to public innovation and sustainability of public organisations. The concept of smartness is rising with regards to advent of agile and smart working practices within relationships at work. The study refers to the analysis of articles referred to public innovation as collaborative innovation. Some articles are considered with regards to the concept of smartness and sustainability in public organisations. The smart working theme is considered as a field of experimentation for public organisations driving innovation by investing in smart and sustainable solutions to address public value creation. The selected contributions are drawn by literature related to smart and sustainable public organisations in relation to the use of ICT that enables both smart working practices to define an innovative and collaborative approach to digital and smart work organisation as evolution of the use of advanced information technology in government. The selected contributions are interpreted in a narrative synthesis in order to elucidate new perspectives and advance theoretical frameworks on emerging issues $[35,36]$.

\section{Driving collaborative innovation}

Innovation is a discontinuity with the past and refers to development and implementation of new ideas that disrupt the common wisdom and improve existing practices $[18,37]$. It is about searching new ideas and ways of thinking and performing tasks in order to produce a qualitative change [38, 39]. Public sector innovation develops through collaborative processes that involve public and private organisations, and facilitate value co-creation processes [17], coherently with a service logic view [1]. Collaborative innovation helps to transform government in a significant way [40] and to bring together similarity of education and values and diversity of ideas to stimulate creative problem solving [6]. Ensuring trust and legitimacy of government is an important driver for public sector innovation [41]. Innovation is a not linear process. Collaborative innovation is multi-actor-based, involves actors from within the organisation, other organisations, the private and third sector and citizens that are integrated in the innovation cycle, engaging in a trust-based dialogue and exploiting their differences for innovative solutions [6, 42]. Public managers enable open and flexible spaces for collaborative interaction between government and nongovernment actors. In particular, the leadership role enables innovation and value creation [38]. Public sector innovation relates to collaborative interaction among public and private actors such as politicians, civil servants, private firms and community-based associations [39]. Digital public service innovation as collaborative process helps both value co-creation and development of public-private partnerships [43]. The advent of digital and interactive information technology helps to strengthen collaborative public co-production and co-creation, leading to both open public innovation [44], unexpected and favourable organisational and behavioural issues [45]. Digital government systems and digitalisation are leading to collaborative processes [46]. 
Employees are explorers of new innovation opportunities. Technology helps public organisations to develop open innovation by including external knowledge in decision-making processes [19].

\section{Sustainable and smart public organisations by technology}

Public organisations achieve the sustainability as a vision for change by managing res publica within communities, following a service logic view and public value orientation $[1,2,3,4,5]$. Technology opens up to digital and smart public organisations as enablers of social and public value creation by involving civil society and promoting citizen-centred services effectiveness [20,21]. Sustainable public organisations use digital technology in order to enhance services coproduction, enabling a relational process with public service users [47]. Digitalisation is leading to smart public organisations able to manage complexity by using simplicity, intelligence and collaboration [23]. Digital transformation in public sector organisations enables smart platforms and collaborative spaces in order to drive value creation processes and support cultural and organisational changes and innovation enabled by skills and competences of employees and managers [1,34, 48, 49]. Technology helps to shape flexible, agile and adaptive public organisations [50]. Digitalisation in government helps to strengthen processes of cooperation, engagement and participation in policymaking and services design [51]. Digital technology encourages a community/citizen centred approach to public services design [52], enabling public organisations to empower the citizen as a responsible partner in co-production of public services [53], towards a networked co-production and value co-creation [54]. As using information technology, smart and innovative public organisations contribute to new services and interact with citizens in order to improve their quality of life [55].

Smart government initiatives support innovativeness and collaboration [21]. Information technology in government catalyses innovations and helps to develop smart, agile and resilient organisations [56]. Innovation is a key dimension of smartness which supports sustainability in government [16]. As key components of government administrative reform, information technologies are leading to a smart State, strengthening inter-organisational collaboration, information sharing and integration [57]. The advent of information, interactive and digital technology helps to drive sustainable public organisations which support a community/citizen approach, encouraging privatepublic partnerships by involving citizens in policymaking [33, 52]. The use of information technology in government is leading to sustainable, digital and smart public organisations [31, 33, 58]. Public organisations support public value creation by developing digital technology, promoting co-construction and coinnovation where the locus of co-production is the service system [59, 60]. Smart government initiatives involve private and public actors to develop knowledge and capabilities in the pursuit of public goals in order to improve quality of life for people and communities [15, 32].

\section{Driving smart working collaborative innovation}

Today, the potential offered by information technology helps to support smart or agile working practices. The advent of smart working practices is changing the way by which people interpret the meaning of work in their life, dealing with work-life balance management too. The work will be smart in the future. Smart working can emerge as an innovative way of considering the work as a means to foster collaborative and innovative spaces within work environments. Smart working is emerging as an innovative approach for work organisation redesign by redefining the relationships between the employee and organisation [61]. The rise and widespread diffusion of smart working-oriented practices opens up to a new smart workplace as a collaborative space which enables employees to use the technology as a mean for strengthening interaction and collaboration, reinforcing shared norms, goals and identification. Public organisations are developing the potential of technological advancements in order to offer their employees new ways of work design, overcoming physical and time barriers, promoting telework, homebased and mobile work organisation modes [62]. Public organisations are embracing smart working practices to ensure efficiency and effectiveness, and to enhance flexibility and autonomy, promoting collaboration [63]. Public organisations are driving smart working practices, giving value to the relationships between the administration and the employees [62, 63]. Driving smart working helps to shape results-driven and collaboration-oriented organisations, strengthening the role of managers who empower the employees at work by following a collaborative approach [64].

Smart and agile work or ubiquitous working is conceived as a new way to design work organisation which may benefit both the employee, ensuring smart work-life balance, improving costs reduction and driving productivity improvement. Smart work refers to resultsoriented, social and collaborative organisational spaces which open up to a networked way of operating [65] Smart working refers to an organisational model that strengthens autonomy to achieve the results. It relies on an intelligent rethinking of the way by which work activities are carried out in order to leverage the employees' innovation potential [66].

Digitalisation helps to enhance collaborative spaces and blended forms of work with regards to physical, digital and relational aspects [67]. Smart working helps to support cultural change and requires organisational innovation for which a detailed roadmap must be provided [24] 
Smart working empowers employees' autonomy, flexibility and accountability for results in their work. Smart working supports both social collaboration and managers who are able to promote sense of community, empowerment, flexibility. Organisational policies, technology, physical layout and leadership behaviours and styles exert influence on effective smart working practices [68] to support larger autonomy, foster confidence and propensity towards innovation [69] and facilitate customer-focused and value-based relationships that benefit the organisation and people [70].

Smart working helps to drive organisational innovation as a means to support cultural change [24]. Smart working helps to foster an openness-driven and knowledge-exchange-oriented smart organisational culture in work environment. Smart working is emerging as a collaborative space for flexible work and workplace which enhances changing attitudes and behaviours of both employees and their managers [71], enabling leadership as a source to ensure flexibility, coherence and integration [73].

Smart working allows a better balance between quality of life and individual productivity, and focuses on integration, collaboration and governance [72]. Managers actively drive high performance and satisfaction of employees working by technology between home and office in order to develop favourable employee relationships [25]. Smart working enhances the role of middles managers who behave as coaches than controllers, encouraging employee autonomy and self-management [26].

\section{Discussion and conclusions}

Sustainability-oriented and smart-driven public organisations are using technological advancements and developments in order to drive collaborative innovation and change the way by which employees and organisations relate to workplace management. Digital transformation in public sector drives processes that support collaboration and empowerment at work, reinforcing the relationships between employees and managers. Public organisations strengthen the potential of digital and smart government in order to gain the benefits of technological innovation that enables organisations and employees to value creation. Innovation always concerns the life and development of sustainability-oriented public organisations. ICT and digital technologies help public organisations to adopt a smart view to work organisation redesign for sustainability.

Smart and sustainable public organisations contribute to value creation processes developing the potential of information technology and empowering people, rediscovering the central role of public managers in the relationship with employees. Smart working is becoming a new collaborative arena that enables collaborative innovation in work processes, shaping behaviours and attitudes of employees and managers at work.

Smart and sustainable public organisations develop behavioural and technological capabilities in order to enable collaborative and innovative work spaces. Smart working organisations support collaborative innovation and enable the transition from managing work relationships and processes to driving innovation in behaviours, relationships and cultural values at work, sustaining commitment and public service motivation of employees at work. Public managers strengthen the potential of social and human relationships as sustained by information technology in order to promote sources and capabilities for innovation.

As shown in Figure 1, the main contribution of the study is to identify some pathways that enable smart and sustainable public organisations which are developing the potential of information technology to promote the transition from technology-enabled working to smart working, moving both from management to innovation, and from organisation to fostering working and collaborative spaces.

Fig. 1. Towards smart and sustainable public organisations

\begin{tabular}{c|c|c|}
\multirow{1}{*}{$\begin{array}{c}\text { from } \\
\text { from } \\
\text { organisation }\end{array}$} & $\begin{array}{c}\text { Technology-enabled } \\
\text { Public Organisations }\end{array}$ & $\begin{array}{c}\text { Smart-driven } \\
\text { Public Organisations }\end{array}$ \\
\cline { 2 - 3 } $\begin{array}{c}\text { to } \\
\text { collaborative } \\
\text { spaces }\end{array}$ & $\begin{array}{c}\text { Innovation-driven } \\
\text { Public Organisations }\end{array}$ & $\begin{array}{c}\text { Smart and Sustainable } \\
\text { Public Organisations }\end{array}$ \\
\cline { 2 - 3 } & from management & to innovation
\end{tabular}

Public organisations rethink a smart and sustainable view to work processes, strengthening the role of public managers who promote collaborative processes within and between organisation and society, playing a key role in driving cultural change and innovation processes. Sustainable public organisations foster collaborative innovation by using the information and communication technology as a means to support smart working, innovative behaviours of employees, agile policies and practices, and enforce cooperative work and management at work. The use of ICT, digital and interactive technology helps to drive sustainable public organisations. The future of sustainable public organisations relies on supporting smart-oriented work relationships that engender managers-employee collaborative spaces enabled by the rise of digital applications and devices. With the advent of pandemic health crisis, the opportunities offered by technology at work in terms of smart and agile working have helped to ensure the continuity of performances at work and enhance the sustainability of organisations, by restoring the relationships between the individual and the organisation. In virtue of pandemic crisis, smart working practices have been introduced, but the response to health crisis has emphasized the rise of a technologyenabled work in emergency but could not drive the advent of smart, agile or sustainable work. As the technology-enabled work has been considered as extraordinary and temporary work in the first stage of pandemic crisis, organisations have experimented practices and procedures to enable mechanisms of 
coordination for new flexible, digital and physical work regarding the employees and their relationships with organisations' management and rules. Today, smart and sustainable working public organisations promote technology-driven work relationships combining both digital and physical infrastructures at work by developing collaborative innovation and enabling digital and collaborative work environments. The future of work and organisation will be smart as managers and employees build and share innovative solutions, strengthening proactive collaboration.

In this study, there are some limitations. This study identifies only a theoretical framework of analysis in order to identify the pathway leading to smart and sustainable public organisations promoting innovation by using the potential of information technology and driving smart working as a change vision to work processes and work innovation that enhances collaborative aspects of the employee-manager relationships. Thereby, there are no case studies and empirical research presented in the analysis. Public organisations are still in infancy in rethinking a smart mind set and planning about how to deal with smartness and sustainability as key drivers for organisational change and collaborative innovation at work. Further research perspectives and investigations will consider how smart working practices have influenced human resource management policies within public organisations.

\section{References}

1. S.P. Osborne, From Public Service-Dominant Logic to Public Service Logic: Are Public Service Organizations Capable of Co-Production and value Co-Creation?, Public Management Review, 20, 2 (2018)

2. G. Stoker, Public Value Management. A New Narrative for Networked Governance?, American Review of Public Administration 36, 1 (2006)

3. C.T. Goodsell, A New Vision for Public Administration, Public Administration Review, 66, 4 (2006)

4. D.J. Fiorino, Sustainability as a Conceptual Focus for Public Administration, Public Administration Review, 70 (2010)

5. J. Dumay, J. Guthrie, F. Farneti, GRI Sustainability Reporting Guidelines for Public and Third Sector Organizations. A critical review, Public Administration Review, 12, 4 (2010)

6. J. Törfing, Collaborative innovation in the public sector: The argument, Public Management Review, 21, 1 (2019)

7. D. Matheson, J.E. Matheson, Smart organizations perform better, Research-Technology Management, 44, 4 (2001)
8. J. Pfeffer, When it comes to "best practices" Why do smart organizations occasionally do dumb things, Organizational Dynamics, 25, 1 (1996)

9. J. Pfeffer, Building Sustainable Organizations: The Human Factor, Academy of Management Perspectives, 24, 1 (2010)

10. K.H. Aggerholm, E.S. Andersen, C. Thomsen, Conceptualising employer branding in sustainable organisations, Corporate Communications: An International Journal, 16, 2 (2011)

11. J. Pfeffer, Producing sustainable competitive advantage through the effective management of people, Academy of Management Perspectives, 9, 1 (1995)

12. R.D. Leon, From the Sustainable Organization to Sustainable Knowledge-Based Organization, Economic Insights-Trends \& Challenges, 65, 2 (2013)

13. B.E. Perrott, Building the sustainable organization: an integrated approach, Journal of Business Strategy, 36, 1 (2015)

14. H.M. Haugh, A. Talwar, How Do Corporations Embed Sustainability Across the Organization?, Academy of Management Learning \& Education, 9, 3 (2010)

15. J.R. Gil-Garcia, J. Zhang, G. Puron-Cid, Conceptualizing Smartness in Government: An Integrative and Multi-Dimensional View, Government Information Quarterly, 33, 3 (2016)

16. R.B. Denhardt, J.V. Denhardt, The New Public Service: Serving Rather than Steering, Public Administration Review, 60, 6 (2000)

17. C. Ansell, J. Törfing, Public innovation through collaboration and design (London, Routledge, 2014)

18. I. Hartley, Innovation in Governance and Public Services: Past and Present, Public Money \& Management, 25, 1 (2005)

19. I. Mergel, Open innovation in the public sector: drivers and barriers for the adoption of Challenge.gov, Public Management Review, 20, 5 (2018)

20. M.H. Moore, Creating Public Value. Strategic Management in Government (Harvard Business Press, Cambridge, 1995)

21. K. Schendler, A.A. Guenduez, R. Frischknecht, How can smart government be? Exploring barriers to the adoption of smart government, Information Polity, 24, 1 (2019)

22. Politecnico di Milano Osservatorio sullo smart working. Retrieved at: https://www.osservatori.net/it/ricerche/osservatoriattivi/smart-working (2021)

23. E. Viceconte, Smart è l'organizzazione, non il lavoro, Prospettive in organizzazione Vol. 13 - Will employees dream of electric sheep? Gli effetti della tecnologia sul lavoro e i lavoratori (2020) 
24. T. Torre, D. Sarti, Into Smart Work Practices: Which Challenges for the HR Department?, E. Ales, Y. Curzi, T. Fabbri, O. Rymkevich, I. Senatori, G. Solinas, Working in Digital and Smart Organizations (Palgrave Macmillan, Cham, 2018)

25. L. Harris, Home-based teleworking and the employment relationship. Managerial challenges and dilemmas, Personnel Review, 32, 4, (2003)

26. C. Dambrin, How does telework influence the manager-employee relationship?, International Journal of Human Resources Development and Management, 4, 4 (2004)

27. F. Munir, S.J. Biddle, M.J. Davies, D. Dunstan, D. Esliger, L.J. Gray,..., C.L. Edwardson, Stand More AT Work (SMArT Work): using the behaviour change wheel to develop an intervention to reduce sitting time in the workplace, BMC public health, 18, 1 (2018)

28. M. Van Wart, Lessons from Leadership Theory and the Contemporary Challenges of Leaders, Public Administration Review, 73, 4 (2013)

29. M. McGuire, Collaborative public management: Assessing what we know and how we know it, Public Administration Review, 6 (2006)

30. S.P. Osborne, The New Public Governance? Emerging Perspectives on the Theory and Practice of Public Governance(Routledge, London and New York, 2010)

31. B. Granier, H. Kudo, How Are Citizens Involved in Smart Cities? Analysing Citizen Participation in Japanese 'Smart Communities', Information Polity, 21, 1 (2016)

32. T. Janowski, T.A. Pardo, J. Davies, Government Information Networks - Mapping Electronic Governance Cases Through Public Administration Concepts, Government Information Quarterly, 29 (2012)

33. H. Larsson, Á. Grönlund, Future-oriented eGovernance: The Sustainability Concept in eGov Research, and Ways Forward, Government Information Quarterly, 31 (2014)

34. J.M. Bryson, B.C. Crosby, L. Bloomberg, Public Value Governance: Moving Beyond Traditional Public Administration and the New Public Management, Public Administration Review, 74, 4 (2014)

35. D. Denyer, D. Tranfield, Using Qualitative Research Synthesis to Build an Actionable Knowledge Base, Management Decision, 24 (2006)

36. M. Dixon-Woods, S. Agarwall, B. Young, D. Jones, A. Sutton, Integrative Approaches to Qualitative and Quantitative Evidence, Health Development Agency, London, available at www.hda.nhs.uk (2004)

37. S.P. Osborne, L. Brown, Innovation, public policy and public services delivery in the UK. The word that would be king?, Public administration, 89, 4 (2011)
38. B.C. Crosby, P. 't Hart, J. Törfing, Public value creation through collaborative innovation, Public Management Review, 19, 5 (2017)

39. E. Sørensen, J. Törfing, Enhancing collaborative innovation in the public sector, Administration \& Society, 43, 8 (2011)

40. S. Nambisan, Transforming Government through Collaborative Innovation, (IBM Center for the Business Government, 2008)

41. H. De Vries, V. Bekkers, L. Tummers, Innovation in the public sector: A systematic review and future research agenda, Public Administration, 94, 1 (2016)

42. B. Bommert, Collaborative innovation in the public sector, International Public Management Review, 11, 1 (2010)

43. J. Bertot, E. Estevez, T. Janowski, Universal and contextualized public services: Digital public service innovation framework, Government Information Quarterly, 33 (2018)

44. J.I. Criado, T.F. Dias, H. Sano, F. Rojas-Martín, A. Silvan, A.I. Filho, Public innovation and living labs in action: a comparative analysis in Post-New Public Management contexts, International Journal of Public Administration, 44, 6 (2021)

45. A. Scupola, A. Zanferi, Governance and innovation in public sector services: The case of the digital library, Government Information Quarterly, 33, 2 (2016)

46. S.S. Dawes, T.A. Pardo, Building Collaborative Digital Government Systems. McIver, W.J., Elmagarmid, A.K., Advances in Digital Government. Technology, Human Factors, and Policy (pp. 259-274), Kluwer Academic Publishers, London (2002)

47. S.P. Osborne, Z. Radnor, I. Vidal, T.A. Kinder, Sustainable Business Model for Public Service Organizations?, Public Management Review, 16, 2 (2014)

48. T.H. Harrison, T.A. Pardo, M. Cook, Creating Open Government Ecosystems: A Research and Development Agenda, Future Internet, 4, 4 (2012)

49. F. Buonocore, Dalla digitalizzazione alla trasformazione digitale nella PA. La prospettiva organizzativa, Prospettive in organizzazione, Vol. 13 - Will employees dream of electric sheep? Gli effetti della tecnologia sul lavoro e i lavoratori (2020)

50. I. Mergel, Y. Gong, J. Bertot Agile government: Systematic literature review and future research, Government Information Quarterly, 35, 2 (2018)

51. OECD. Recommendation of the Council on Digital Government Strategies, (Public Governance and Territorial Development Directorate, 2014)

52, P. Dunleavy, H. Margetts, S. Bastow, J. Tinkler, New Public Management is Dead-Long Live Digital-Era Governance, Journal of Public Administration Research and Theory, 16, 3 (2005) 
53. D. Linders, From E-government to We-Government: Defining a Typology for Citizen Coproduction in The Age of Social Media, Government Information Quarterly, 29, 4 (2012)

54. J. Fishenden, M. Thompson, Digital Government, Open Architecture, and Innovation: Why Public Sector IT Will Never Be the Same Again, Journal of Public Administration Research and Theory, 23, 4 (2013)

55. S. Mellouli, L.F. Luna-Reyes, J. Zhang, Smart government, citizen participation and open data, Information Polity, 19, 1-2 (2014)

56. J.R. Gil-Garcia, N. Helbig, A. Ojo, Being smart: Emerging technologies and innovation in the public sector, Government Information Quarterly, 31, 1 (2014)

57. J.R. Gil-Garcia, Towards a smart State? Inter-agency collaboration, information integration, and beyond, Information Polity, 17, 3-4 (2012)

58. T. Janowski, Digital Government Evolution: From Transformation to Contextualization, Government Information Quarterly, 32, 3 (2015)

59. S.P Osborne, The New Public Governance, Public Management Review, 8, 3 (2006)

60. S.P. Osborne, Z. Radnor, K. Strokosch, Coproduction and The Co-Creation of Value in Public Services: A Suitable Case for Treatment?, Public Management Review, 18, 5 (2016)

61. M. Decastri, F. Gagliarducci, P. Previtali, D. Scarozza, Understanding the Use of Smart Working in Public Administration: The Experience of the Presidency of the Council of Ministers. A. Lazazzara, F. Ricciardi, S. Za, Exploring Digital Ecosystems. Organizational and Human Challenges (Springer, Cham 2020)

62. R. Reina, D. Scarozza, Human Resource Management in the Public Administration, M. Decastri, S. Battini, F. Buonocore, F. Gagliarducci, Organizational Development in Public Administration. The Italian Way (Palgrave Macmillan, Cham, 2020)

63. A. Ravarini, R. Cuel, L. Varriale, Lo smart working nelle pubbliche amministrazioni: un'analisi sociotecnica del fenomeno, Prospettive in organizzazione, Vol. 14 - Le Sfide del management pubblico: nuovi modelli organizzativi (2020)

64. Politecnico di Milano, Lavoro Agile per il futuro della PA. Approfondimento delle esperienze più significative di lavoro agile realizzate a livello pubblico e privato sia in ambito nazionale sia internazionale. Progetto "Lavoro agile per il futuro della PA" PON Governance e capacità istituzionale 2014/2020, Asse 1, Azione 1.3.5 (2018)

65. F. Butera, Le condizioni organizzative e professionali dello smart working dopo l'emergenza: progettare il lavoro ubiquo fatto di ruoli aperti e di professioni a larga banda, Studi Organizzativi, 1 (2020)
66. L. Gastaldi, M. Corso, E. Raguseo, P. Neirotti, E. Paolucci, A. Martini, Smart working: Rethinking work practices to leverage employees' innovation potential, 15th CINet Conference (Vol. 100) (2014)

67. F. Montanari, La digitalizzazione degli spazi collaborativi: verso forme blended di lavoro? Prospettive in organizzazione, Vol. 13 - Will employees dream of electric sheep? Gli effetti della tecnologia sul lavoro e i lavoratori (2020)

68. F. Crespi, Lo Smart Working in Italia: la diffusione del fenomeno, Osservatorio Smart Working, Politecnico di Milano (2016)

69. V. Langè, L. Gastaldi, Coping Italian Emergency COVID-19 through Smart Working: From Necessity to Opportunity, Journal of Mediterranean Knowledge, 5, 1 (2020)

70. A.M. McEwan, Smart working: Creating the next wave (CRC Press, 2016)

71. L. Errichiello, T. Pianese, Toward a theory on wrokplaces for smart workers, Facilieties, 38, 3-4 (2020)

72. J.Y. Hur, W. Cho, G. Lee, S.H. Bickerton, The "smart work" myth: how bureaucratic inertia and workplace culture stymied digital transformation in the relocation of South Korea's capital, Asian Studies Review, 43, 4 (2019)

73. M. Iannotta, C. Meret, Flessibilità, coerenza, integrazione: tre leve per una leadership efficace a supporto dello smart working, Prospettive in organizzazione, Vol. 13- Will employees dream of electric sheep? Gli effetti della tecnologia sul lavoro e i lavoratori (2020) 